\title{
ANALYSIS THE EFFECT OF WEB QUALITY AND FULFILLMENT ON SATISFACTION AND ITS IMPACT ON REPURCHASE INTENTION
}

\author{
Rizky Fauzan ${ }^{1 *}$, Damianus Ute ${ }^{1}$ \\ ${ }^{1}$ Economic and Business Faculty, Tanjungpura University, Pontianak \\ *Email corresponding author: rizkyfauz@yahoo.co.id \\ Received 04/01/2021 Revised 19/01/2021 Published 31/01/2021
}

\begin{abstract}
The purpose of this study was to analyze the effect of web quality, fulfillment, and satisfaction and its impact on repurchase intention of e-commerce customers. This type of research used survey methods, the population in this study were all Tokopedia consumers in Pontianak cityIndonesia. The sample in this study used 100 respondents using purposive sampling technique and the data analysis carried out with path analysis. Results of the first substructure was fulfillment and web quality had positive effect to satisfaction. The second substructure was the fulfillment did not effect the repurchase intention while the web quality and satisfaction variables has positive effect on repurchase intention. Satisfaction mediated the effect of fullfillment and web quality on repurchase intention.
\end{abstract}

Key Words: Web Quality, Fulfillment, Satisfaction, and Repurchase Intention

\section{INTRODUCTION}

As we know, the development of information technology, especially the internet, has a big influence in every aspect of life, including in the business world. The high number of internet service users triggers business people to do their business activities online because the costs are cheaper and it is easier to do. Currently, some people consider online shopping as a solution in shopping, this is because consumers can get the goods or services they want without having to go to a shopping place, but simply by choosing what they want through the website or application provided by the company.

According to data from GlobalWeblndex, in 2019 Indonesia became the country with the highest e-commerce adoption in the world. The percentage is $90 \%$ of internet users aged 16 years - 64 years have done online shopping. Based on iPrice, here is a list of 10 e-commerce dominating the Indonesian market in the first quarter of 2019, the iPrice version; 1) Tokopedia; 2) Shopee; 3) Bukalapak; 4) Lazada; 5) JD.id; 6) Blibli.com; 7) Zalora; 8) AliExpres; 9) Zilingo Shopping; 10) Amazon. One type of e-commerce which is popular in Indonesia is Tokopedia. Based on the results of a survey conducted by the iPrice Group, Tokopedia has name as the e-commerce with the largest number of monthly web visitors in the third quarter of 2019. Tokopedia's total monthly web visitors are 66 million visitors. The next rank was Shopee with 56 million visitors and Bukalapak with 43 million visitors. However, based on the ranking on the Appstore and Playstore, Shopee leads the way in first place beating Tokopedia. Tokopedia is in the second place on the Appstore, while Lazada is on Playstore.

It is very important for every e-commerce company like Tokopedia to see the level of consumer satisfaction through website quality and the level of fulfillment of promises to win fierce competition for the company survival. Suliyanto et al. (2019) stated that to be able to satisfy customers, a company must know what the customer needs and wants. According to Tjiptono (2014), website quality greatly affected the level of user satisfaction. Understandable website content, clear information, and security need be pid attetion to in order to be able to make customers feel satisfied with website services. In addition to providing a website quality, the company must also pay attention to the level of fulfillment such as the availability of product items, the estimated time for product delivery, and ensure the condition of the product that reaches the 


\section{PERFORMANCE}

Jurnal Personalia, Financial, Operasional,

Marketing dau Sistem Informasi

Performance. Volume 28 Nomor 1 Tahun 2021, 82-92

customer is the same as shown as on the website. Fulfillment is the ability of how online stores ensure customers get what they order (Blut, 2016). Customers will feel satisfied and intend to make repeat purchases if the quality of a website and the fulfillment of the website promises are as expected by the customer. In this study, a mediating variable is added, namely satisfaction, because to make someone repurchase, it must be driven by a sense of satisfaction that comes from fulfillment and the quality of the web.

\section{LITERATURE REVIEW AND HYPOTHESIS DEVELOPMENT}

\section{E-Service Quality}

According to Fandy Tjiptono (2014), he defined e-service quality as how well the site facilitates effective and efficient shopping in terms of purchasing, marketing, and shipping. EService Quality includes all stages of customer interaction with the website: how well the website makes it easier and more efficient to shop, to make purchases, and to deliver (Parasuraman, et al., 2005). The dimensions of e-service quality consist of: 1) Efficiency, the ability to provide services to customers to access websites, to find products and to get information needed related to products or companies easily and quickly. 2) System Availability, the technical functionality of the site concerned, in particular how well the company is able to provide accurate or error-free services and function properly. 3) Fulfillment, how well an online site's promises regarding order delivery and order availability are fulfilled. 4) Privacy, which is the level at which the online site is safe and protects customer information.

\section{Repurchase Intention}

According to Schiffman (2010), repurchasing is a purchase activity that is carried out more than once or several times. Repurchase intention arises after customers get satisfaction with a product or service. Repurchase intention arises due to the perception that the product is in a good quality. According to Ferdinand (2002), repurchase intention can be identified through several dimensions as follows: 1) Transactional Intention, a person's tendency to buy a product. 2) Referential Intention, the tendency of a person to refer to others. 3) Preferential Intention, intention that describes the behavior of a person who has a preferential main to the product, this preference can only be replaced if something happens to the product of his preference. 4) Explorative Intention, this intention describes the behavior of a person who is always looking for information about the product he is requesting and looking for information to support the positive properties of the same product.

\section{Satisfaction}

Customer satisfaction is the result of a comparison between customer expectations of the company's products and services and what they receive. Ranjbarian, et al. (2012) defined that esatisfaction or online customer satisfaction is the result of consumer perceptions of online convenience, trading / transaction methods, site design, security, and services. According to Ranjbarian, et al. (2012), there are 4 dimensions that affect e-satisfaction: 1) Convenience, online shopping can save time and effort by making it easier to find merchants, to find goods, and to get offers. 2) Merchandising, According to Ranjbarian, et al. (2012), a richer (wider and higher quality) information is available online to produce better purchasing decisions and higher levels of esatisfaction. 3) Site Design, good website design is all about good organization and easy searching. Includes an uncluttered display screen, simple search paths, and fast presentations. 4) Security, Security is related to how a website proves to be trusted for its customers.

\section{Web Quality}

According to Barnes \& Vidgen (2002), website quality is an instrument developed to assess the usefulness of information and the quality of service interactions from internet websites. The quality of the web is one of the factors that companies must pay attention to in order to increase 


\section{PERFORMANCE}

Jurnal Personalia, Financial, Operasional,

Marketing dau Sistem Informasi

Performance. Volume 28 Nomor 1 Tahun 2021, 82-92

their competitive advantage, according to the findings of research conducted by Lathiras, et al. (2011) found that the high technology reality where the virtual world has become very important, the quality of the web should not be ignored by companies who want to remain competitive and grow, especially for e-commerce companies. According to Barnes \& Vidgen (2002), the dimensions of website quality consist of three: 1) Information Quality, Information quality includes things such as accurate information, reliable information, information that is up to date and latest, information in line with the topic of discussion, information that is easy to understand, information that is very detailed, and information is presented in an appropriate design format. 2) Interaction Quality, Quality of interaction includes the ability to provide a sense of security when transacting, has a good reputation, facilitates communication, creates more personal emotional feelings, has confidence in storing users' personal information, is able to create a more specific community, is able to give confidence that the promises delivered will be kept. 3) Usability Quality, Quality of use is easy to learn, easy to understand, easy to search for, easy to use, very attractive, displays a pleasant visual form, has good competence, and provides a pleasant new experience.

\section{Fulfillment}

Fulfillment (fulfillment of promises) according to Parasuraman, et al. (2005), fulfillment as a dimension of electronic service quality, fulfillment is defined as the level of fulfillment of promises provided by the website. According to Koufteros, et al. (2014), there are three dimensions of fulfillment of promises: 1) Availability, refers to the ability of a website to meet the availability of a product or service. 2) Time, which refers to the fulfillment of promises in the timeliness of delivery of products or services as promised on a website. 3) Condition, refers to whether the product ordered arrives in good condition and in line with what is displayed on the website.

\section{The Effect of Fulfillment on Satisfaction}

An important factor for assessing the quality of an online business is the accuracy of promises because keeping service promises and accurate order fulfillment are elements of service quality that lead to customer satisfaction or dissatisfaction (Suprityantini, et al., 2014). The better the level of fulfillment of promises such as delivery, ordering, availability and condition of products or services from the quality of services provided, the better customer satisfaction. Research conducted by Supriyantini, Suyadi \& Riyadi (2016), Jain, Shah \& Sadh (2017), and Rohwiyati \& Praptiestrini (2019) stated that fulfillment has a positive effect on customer satisfaction. Based on the description above, the first hypothesis in this study is formulated as follows:

$\mathrm{H}_{1}$ : Fulfillment has a positive effect on customer satisfaction.

\section{The Effect of Web Quality on Satisfaction}

Web quality is an Information Technology platform (Liu \& Arnett, 2000). Website is an important component of e-commerce success for some organizations (Giao \& Quan, 2020). The success of a company can be measured through customer satisfaction, because customer satisfaction is the key to winning the competition. According to Tjiptono (2014), website quality greatly affects the level of user satisfaction itself. Website content that is easy to use, has clear information, and secure need to be really paid attention to because it is able to make customers feel satisfied with the services provided. Research conducted by Rinaldi \& Santoso (2018), Muhsin \& Zullestiana (2017), Kurniawati, et al. (2018), Jauhari, Kusumawati \& Nuralam (2019), Pham \& Nguyen (2019) stated that web quality affected customer satisfaction. Based on the description above, the second hypothesis in this study is formulated as follows:

$\mathrm{H}_{2}$ : Web Quality has a positive effect on customer satisfaction. 


\section{PERFORMANCE}

Jurnal Personalia, Financial, Operasional,

Marketing dau Sistem Informasi

Performance. Volume 28 Nomor 1 Tahun 2021, 82-92

\section{The Effect of Fulfillment on Repurchase Intention}

Fulfillment is all about meeting customer expectations and satisfaction, a process that starts with accepting a customer order and ends with accepting the customer exactly what she or he wants, when and where she or he wants it (Tarn, et al., 2003). Fulfillment of customer expectations in line with the promises displayed on the web will make consumers feel satisfied and have an impact on consumer intention to make repeat purchases. Previous research conducted by Jain, Shah \& Sadh (2017) showed that fulfillment had a significant positive effect on repurchase intention. Based on this description, the third hypothesis in this study is formulated as follows:

$\mathrm{H}_{3}$ : Fulfillment has a positive effect on customer Repurchase Intention.

\section{The Effect of Web Quality on Repurchase Intention}

According to Barnes \& Vidgen (2002), website quality is an instrument developed to assess the usefulness of information and the quality of services interactions from internet websites. Website content that is easy to use, has clear information, and secure need to be paid attention to in order to be able to make customers feel satisfied with the services provided. The better the quality of the website, the better the experience for consumers, which will be a consideration for customers to repurchase products / services. Previous research conducted by Rinaldi \& Santoso (2018), Huyen Pham \& Thu Nguyen (2019), stated that web quality has a significant effect on repurchase intention. Based on the description stated above, the fourth hypothesis in this study can be formulated as follows:

$\mathrm{H}_{4}$ : Web quality has a positive effect on customer Repurchase Intention.

\section{The Effect of Satisfaction on Repurchase Intention}

According to Lovelock \& Writz (2011), satisfaction is an attitude that is decided based on the experience gained. Customer satisfaction is a level where the needs, wants, and expectations of the customer can be fulfilled which results in repeat purchases or continued loyalty. Satisfying customer needs is important for the survival of the company, besides satisfying customer needs can increase competitive advantage. In a study conducted by Saputri, Rahayu and Astuti (2016), it was stated that there was a significant positive effect between customer satisfaction and repurchase intention. Intention in repurchasing is one indicator of loyalty, Hayati et al., 2020 stated that customer satisfaction has a positive effect on loyalty. Based on the description stated above, the fifth hypothesis in this study can be formulated as follows:

$\mathrm{H}_{5}$ : Customer satisfaction has a positive effect on repurchase intention.

Based on the development of the above hypothesis, the research model can be described as follows:

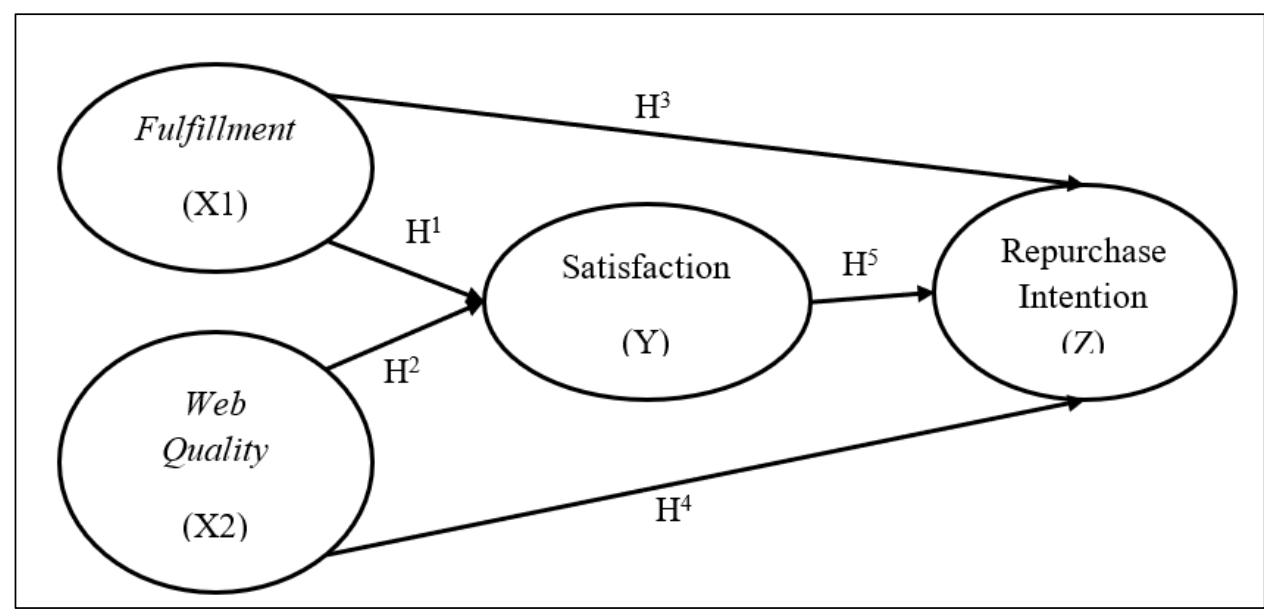

Figure 1. Research Framework 


\section{RESEARCH METHODOLOGY}

This research is a causal associative research type and the data type is quantitative. The population in this study were all Tokopedia customers because Tokopedia are one of the unicorn e-commerce in Indonesia. The research was conducted in Pontianak-Indonesia with the samples of 100 Tokopedia customers (the minimum number of samples if the population is very large). The sampling technique used in this study was purposive sampling. The sample criteria in this study are: 1) Respondents are at least 17 years old. 2) Respondents have made purchases using the Tokopedia application at least 2 times in the last 3 months. 3) The respondent is domiciled in Pontianak City. The data collection technique in this research is a questionnaire distributed online using google forms. Data processing was done using SPSS version 23, data analysis was done using path analysis.

\section{RESULT AND DISCUSSION}

Table 1. Profile of Respondents

\begin{tabular}{|c|c|c|c|}
\hline $\begin{array}{c}\text { Profile of } \\
\text { Respondents }\end{array}$ & Information & Total & Percentage \\
\hline \multirow[t]{3}{*}{ Gender } & Male & 36 & 36 \\
\hline & Female & 64 & 64 \\
\hline & Total & 100 & 100 \\
\hline \multirow[t]{6}{*}{ Age } & 17 - 22 year-old & 82 & 82 \\
\hline & 23 - 28 year-old & 17 & 17 \\
\hline & 29 - 34 year-old & 1 & 1 \\
\hline & 35 - 40 year-old & 0 & 0 \\
\hline & $>40$ year-old & 0 & 0 \\
\hline & Total & 100 & 100 \\
\hline \multirow[t]{8}{*}{ Job } & Student & 0 & 0 \\
\hline & University Student & 80 & 80 \\
\hline & Entrepreneur & 2 & 2 \\
\hline & Civil Servant & 0 & 0 \\
\hline & Private Employee & 6 & 6 \\
\hline & Housewife & 0 & 0 \\
\hline & Others & 12 & 12 \\
\hline & Total & 100 & 100 \\
\hline \multirow[t]{7}{*}{ Income } & $\leq$ Rp. 2000.000 & 43 & 84 \\
\hline & > Rp. 2000.000-Rp.3000.000 & 5 & 9,80 \\
\hline & > Rp. 3000.000-Rp.4000.000 & 2 & 3,92 \\
\hline & > Rp. 4000.000-Rp.5.000.000 & 0 & 0 \\
\hline & > Rp. 5000.000-Rp.6000.000 & 0 & 0 \\
\hline & > Rp. 6000.000 & 1 & 1,96 \\
\hline & Total & 51 & 100 \\
\hline
\end{tabular}

Based on table 1, it can be seen that most of the respondents (64\%) are female, this is due to the characteristics in Indonesia that women have a higher frequency of shopping online than men. Most of the respondents based on age are 17-22 years old, this is because most of them are students. Students are one of the target markets for Tokopedia because they have high online shopping literacy. Since most of the respondents are students, the income of the respondents is mostly $\leq$ Rp. 2000,000, because the source of income is only pocket money from their parents. 
Jurnal Personalia, Financial, Operasional,

Marketing dam Sistem Informasi

Performance. Volume 28 Nomor 1 Tahun 2021, 82-92

Validity test

The validity test in this study used item analysis, namely correlating the score of each item with the total score which is the sum of each item score. In this study, the validity was measured by the Pearson product moment, where to determine the appropriateness of an item to be used, a significant correlation coefficient was tested at the 0.05 level.

Table 2. Validity Test of Research Instruments

\begin{tabular}{|c|c|c|c|c|}
\hline Research Variable & Indicator & Correlation & Sig. & Information \\
\hline \multirow{5}{*}{$\begin{array}{l}\text { Fulfillment } \\
\qquad\left(\mathrm{X}_{1}\right)\end{array}$} & $\mathrm{X} 1.1$ & 0.742 & 0,000 & Valid \\
\hline & $\mathrm{X} 1.2$ & 0.686 & 0,000 & Valid \\
\hline & $\mathrm{X} 1.3$ & 0.759 & 0,000 & Valid \\
\hline & X1.4 & 0.718 & 0,000 & Valid \\
\hline & $\times 1.5$ & 0.622 & 0,000 & Valid \\
\hline \multirow{11}{*}{$\begin{array}{l}\text { Web Quality } \\
\qquad\left(\mathrm{X}_{2}\right)\end{array}$} & $\times 2.1$ & 0.736 & 0,000 & Valid \\
\hline & $\times 2.2$ & 0.638 & 0,000 & Valid \\
\hline & $\times 2.3$ & 0.696 & 0,000 & Valid \\
\hline & $\times 2.4$ & 0.707 & 0,000 & Valid \\
\hline & $X 2.5$ & 0.752 & 0,000 & Valid \\
\hline & $X 2.6$ & 0.740 & 0,000 & Valid \\
\hline & $\times 2.7$ & 0.783 & 0,000 & Valid \\
\hline & $\times 2.8$ & 0.787 & 0,000 & Valid \\
\hline & $\times 2.9$ & 0.664 & 0,000 & Valid \\
\hline & $\mathrm{X} 2.10$ & 0.803 & 0,000 & Valid \\
\hline & X2.11 & 0.653 & 0,000 & Valid \\
\hline \multirow{15}{*}{$\begin{array}{l}\text { Satisfaction } \\
\qquad(Y)\end{array}$} & Y1 & 0.753 & 0,000 & Valid \\
\hline & Y2 & 0.827 & 0,000 & Valid \\
\hline & Y3 & 0.729 & 0,000 & Valid \\
\hline & Y4 & 0.658 & 0,000 & Valid \\
\hline & Y5 & 0.741 & 0,000 & Valid \\
\hline & Y6 & 0.501 & 0,000 & Valid \\
\hline & Y7 & 0.794 & 0,000 & Valid \\
\hline & Y8 & 0.691 & 0,000 & Valid \\
\hline & Y9 & 0.760 & 0,000 & Valid \\
\hline & Y10 & 0.729 & 0,000 & Valid \\
\hline & Y11 & 0.655 & 0,000 & Valid \\
\hline & Y12 & 0.683 & 0,000 & Valid \\
\hline & Y13 & 0.768 & 0,000 & Valid \\
\hline & Y14 & 0.753 & 0,000 & Valid \\
\hline & Y15 & 0.711 & 0,000 & Valid \\
\hline \multirow{4}{*}{$\begin{array}{l}\text { Repurchase Intention } \\
\text { (Z) }\end{array}$} & $\mathrm{Z1}$ & 0.849 & 0,000 & Valid \\
\hline & $\mathrm{Z2}$ & 0.820 & 0,000 & Valid \\
\hline & Z3 & 0.826 & 0,000 & Valid \\
\hline & Z4 & 0.792 & 0,000 & Valid \\
\hline
\end{tabular}

\section{Reliability Test}

The reliability measurement technique in this study uses Cronbach Alpha, where a variable can be said to be reliable if the significance level is $>0.6$ (Sugiyono, 2017). If the question instrument $<0.6$ then the question instrument is not reliable. 
Performance. Volume 28 Nomor 1 Tahun 2021, 82-92

Table 3. Result of Reliability Test

\begin{tabular}{lcc}
\multicolumn{1}{c}{ Research Veriable } & Cronbach's Alpha & Information \\
\hline Fulfillment $\left(\mathrm{X}_{1}\right)$ & 0.741 & Reliable \\
Web Quality $\left(\mathrm{X}_{2}\right)$ & 0.908 & Reliable \\
Satisfaction $(\mathrm{Y})$ & 0.931 & Reliable \\
Repurchase Intention $(\mathrm{Z})$ & 0.839 & Reliable \\
\hline
\end{tabular}

Source: Primary Data Processed, 2020

\section{Hypothesis test}

The $t$ test was conducted to determine the effect of the independent variable on the dependent variable. If the significant value of $t$ is greater than 0.05 , then Ho is accepted, which means that the independent variable has no effect on the dependent variable. Meanwhile, if the significant value is less than 0.05 , then $\mathrm{Ho}$ is rejected, which means that the independent variable partially affects the dependent variable (Ghozali, 2011).

Table 4. Results of Path Analysis of the Effect of Fulfillment, Web Quality on Satisfaction

\begin{tabular}{llccl}
\hline \multicolumn{1}{c}{ Variable } & $\begin{array}{c}\text { Path } \\
\text { Coefficient }\end{array}$ & T count & Sig & Conclusion \\
\hline X1 $\quad$ Fulfillment & 0,183 & 2,781 & 0,007 & Significant \\
X2 $\quad$ Web Quality & 0,726 & 11,011 & 0,000 & Significant \\
\hline Determination Coefficient & $=0,659$ & & & \\
Adj. $R$ Square & $=0,652$ & & & \\
$F_{\text {count }}$ & $=93,728$ & & &
\end{tabular}

Data Table 4 using path analysis shows that the path coefficient value of Fulfillment to satisfaction is 0.183 with a significance value of 0.007 less than 0.05 , while the value of the web quality path coefficient on satisfaction is 0.726 with a significance value of 0.000 smaller than 0.05. , so $\mathrm{H} 1$ which states that fulfillment has a positive effect on satisfaction, and $\mathrm{H} 2$ which states that web quality has a positive effect on satisfaction is accepted.

Table 5. Results of Path Analysis of the Influence of Fulfillment, Web Quality and Satisfaction on Repurchase Intention

\begin{tabular}{llcccc}
\hline & \multicolumn{1}{c}{ Variable } & $\begin{array}{c}\text { Path } \\
\text { Coefficient }\end{array}$ & T count & Sig & Conclusion \\
\hline X1 & Fulfillment & 0,063 & 0,800 & 0,426 & Not Significant \\
X2 & Web Quality & 0,460 & 4,064 & 0,000 & Significant \\
X3 & Satisfaction & 0,322 & 2,775 & 0,007 & Significant \\
\hline
\end{tabular}

$\begin{array}{llr}\text { Determination Coefficient } & =0,622 \\ \text { Adj. } R \text { Square } & =0,610 \\ F_{\text {count }} & =52,656\end{array}$

Data Table 5 using path analysis shows that the coefficient value of the Fulfillment path towards repurchase intention is 0.063 with a significance value of 0.426 greater than 0.05 , so that $\mathrm{H} 3$ which states fulfillment has a positive effect on repurchase intention is rejected. The value of the web quality path coefficient on repurchase intention is 0.460 with a significance value of 0.000 smaller than 0.05 and the value of the path coefficient of satisfaction towards repurchase intention is 0.322 with a significance value of 0.007 less than 0.05 , so $\mathrm{H} 4$ states web quality has a positive effect on repurchase intention, and $\mathrm{H} 5$ which states that satisfaction has a positive effect on repurchase intention is accepted. 
Performance. Volume 28 Nomor 1 Tahun 2021, 82-92

\section{Effect of Fulfillment on Repurchase Intention through Satisfaction}

The indirect effect can be calculated by multiplying the path coefficient of Fulfillment to Satisfaction with the coefficient of Satisfaction to Repurchase Intention, namely (0.183) (0.322) $x$ $100 \%=5.90 \%$ while the direct correlation between Fulfillment and Repurchase Intention is (0.063) $2 \times 100 \%=0.4 \%$. In this case, we can see that the indirect correlation between Fulfillment and repurchase Intention is greater than the direct correlation. This means that the Satisfaction variable can act as an intermediary between the Fulfillment and Repurchase Intention correlation. In addition, it can also be seen through the sobel test, the results of the indirect effect test of this study using the online sobel test obtained t-value (1.96844843)>t-table (1.66071) and significant t $0.04901646<0,05$. This proves that fullfillment mediates the effect of fulfillment on repurchase intention.

\section{The Effect of Web Quality on Repurchase Intention through Satisfaction}

The indirect effect can be calculated by multiplying the path coefficient of Web Quality to Satisfaction with the coefficient of Satisfaction to Repurchase Intention, namely (0.726) (0.322) $x$ $100 \%=23.38 \%$ while the direct correlation between Web Quality and Purchase Intention is $(0.460) 2 \times 100 \%=21.16 \%$. In this case, we can see that the indirect correlation between Web Quality and Repurchase Intention is greater than the direct correlation. This means that the Satisfaction variable can be an intermediary in the correlation between Web Quality and Repurchase Intention. The results of the indirect effect test using the Sobel test showed a significant effect by looking at the t-count value $(2,70092763)>t$-table $(1.66071)$ and significant $t$ $0.00691464<0.05$. This proves that web quality mediates the effect of fulfillment on repurchase intention.

\section{The Effect of Fulfillment on Satisfaction}

Based on the results of testing the first hypothesis $(\mathrm{H} 1)$, it proves that Fulfillment has a positive effect on satisfaction. This shows that the higher the fulfillment, the more satisfying the customer will be. The high response of respondents to the level of fulfillment of promises in line with customer expectations on the Tokopedia application in this study resulted in a high level of customer satisfaction. This fulfillment affects satisfaction because buyers tend to trust more stores that can fulfill their promises. Such as delivering the goods on time, the quality of the goods is the same as the photos, and there is a guarantee if the goods are damaged. These results support previous research conducted by Rohwiyati \& Praptiestrini (2019), Supriyantini, Suyadi \& Riyadi, (2016), Jain, Shah \& Sadh, (2017), which stated that fulfillment has a positive and significant effect on satisfaction.

\section{The Effect of Web Quality on Satisfaction}

Based on the results of testing the second hypothesis $(\mathrm{H} 2)$ it proves that web quality has a positive effect on satisfaction. This shows that the higher the web quality, the more satisfying the customer will be. This shows that the quality of a website is a very important factor for every company to increase customer satisfaction. This is also reinforced by the opinion of Tjiptono (2014), which stated that the quality of the website greatly affects the level of user satisfaction. If we easily access the company website, we will also make it easier to contact the company to ask for the items we need. and that is one of the factors that lead to satisfaction for consumers. For example, on Tokopedia, it is very easy to contact the seller. The findings of this study support previous research conducted by Rinaldi \& Santoso (2018), Muhsin \& Zullestiana (2017), Kurniawati, et al. (2018), Jauhari, Kusumawati \& Nuralam (2019) and Pham \& Nguyen (2019) which stated that Web Quality has a positive and significant effect on satisfaction. 
Performance. Volume 28 Nomor 1 Tahun 2021, 82-92

\section{The Effect of Fulfillment on Repurchase Intention}

Based on the results of testing the third hypothesis $(\mathrm{H} 3)$ it proves that the fulfillment of fulfillment does not have a positive effect on repurchase intention. This shows that the higher the fullfiment is not able to increase the repurchase intention. This result is different from previous research conducted by Jain, Shah \& Sadh (2017) which stated that Fulfillment has a positive and significant effect on Customer Repurchase Intention. This is because the high consumer response to fulfillment of promises does not necessarily make consumers feel satisfied, therefore in addition to paying attention to the level of fulfillment of promises which is part of one of the dimensions of e-service quality, companies should also pay attention to the dimensions of eservice including other qualities such as efficiency, system availability, and privacy in order to make consumers feel satisfied with the services provided by the company through its applications so as to create consumer intentions to make repeat purchases.

\section{The Effect of Web Quality on Repurchase Intention}

Based on the results of testing the fourth hypothesis $(\mathrm{H} 4)$ proves that Web Quality has a positive effect on Repurchase Intention. This shows that the higher the web quality will increase the repurchase intention. These results support previous research conducted by Rinaldi \& Santoso (2018), Huyen Pham \& Thu Nguyen (2019). Website quality is a very important factor for every company to be paid attention to, because website quality is part of the company's ability to provide services to meet customer desires. Therefore, the quality of the website is very important to improve for companies like Tokopedia so that consumers can feel satisfied and will intend to make repeat purchases.

\section{The Effect of Satisfaction on Repurchase Intention}

Based on the results of testing the fifth hypothesis (H5) it proves that satisfaction has a positive effect on repurchase intention. This shows that higher satisfaction will increase repurchase intention. The results of this study support previous research conducted by Rinaldi \& Santoso (2018), Rohwiyati \& Praptiestrini (2019), Jinlong Bao (2015); Jain, Shah \& Sadh (2017); Saputri, Rahayu \& Astuti (2016). Hayati et al., 2020 which stated that customer satisfaction has a positive effect on loyalty. This is because the higher the level of customer satisfaction will make customers intentioned in making repeat purchases through the Tokopedia application.

\section{The Effect of Fulfillment and Web Quality on Repurchase Intention through Satisfaction}

Based on the results of mediation testing using the Sobel test, it is proven that satisfaction mediates the effect of fullfillment and web quality on repurchase intention. This research is supported by research conducted by Rohwiyati \& Praptiestrini (2019), which stated that Fulfillment has a positive effect on Repurchase Intention with Satisfaction as an intervening variable. Based on the data, if the company is able to fulfill its promises and provide a quality website, the buyer will be satisfied. and that satisfaction will encourage them to make repeat purchases. This research is supported by research conducted by Rinaldi \& Santoso (2018), which stated that Web Quality has a positive effect on Repurchase Intention with Satisfaction as an intervening variable.

\section{CONCLUSION}

Based on the test and analysis results, the following conclusions can be stated, Fulfillment and web quality have a positive effect on satisfaction. Satisfaction and web quality have a positive effect on consumer repurchase intention, but fulfillment has no effect on repurchase intention and satisfaction mediate the effect of fullfillment and web quality on repurchase intention. The management of Tokopedia needs to further improve application performance in order not to experience interference, and improve performance in fulfilling promises such as product availability, fast and precise delivery times to customers, and pay attention to and respond to 


\section{PERFORMANCE}

Jurnal Personalia, Financial, Operasional,

Marketing dau Sistem Informasi

Performance. Volume 28 Nomor 1 Tahun 2021, 82-92

complaints from customers regarding the condition of the products and services they receive to ensure that products received by customers are as promised in the application so as to make consumers feel satisfied and enjoy their shopping activities.

This research still has many weaknesses, so that this limitation is expected to be an improvement for future research. The limitation in this study is that it only uses three variables in disclosing the factors that affect repurchase intention, for further research, it is expected to add more other variables. This study only used 100 respondents, so it is necessary to increase the number of samples in order to get varied results. It is also necessary for further research to conduct research with more than one research object in otder to produce a clear comparison with the object of research.

\section{REFERENCE}

Barnes, S.J., \& Vidgen, R.T. (2002). Assessing e-commerce quality with WebQual: An evaluation of the usability, informaton quality, and interaction quality on Internet bookstores. Journal of Electronic Cormerce Research, 3, 114-127

Blut, et al. (2015). E-Service Quality: A Meta-Analitic Review. Journal of Retailing, 91 (4).

Ferdinand, A. (2002). Pengembangan Minat Beli Merek Ekstensi. Semarang: Badan Penerbit Universitas Diponegoro.

Ghozali, I. (2011). Aplikasi Analisis Multivariate Dengan Program SPSS. Semarang: Badan Penerbit Universitas Diponegoro.

Giao, H., Vuong, B., \& Quan, T. (2020). The influence of website quality on consumer's e-loyalty through the mediating role of e-trust and e-satisfaction: An evidence from online shopping in Vietnam. Uncertain Supply Chain Management, 8(2), 351-370

Hayati, S., Suroso, A., Suliyanto, S., \& Kaukab, M. (2020). Customer satisfaction as a mediation between micro banking image, customer relationship and customer loyalty. Management Science Letters, 10(11), 2561-2570.

Huyen Pham \& Thu Nguyen (2019). The Effect Of Website Quality On Repurchase Intention With The Mediation Of Perceived Value: The Case Study Of Online Travel Agencies In Vietnam. Journal Of Global Business Insights. 4 (1).

Jain, K.N., et al. (2017). E-fulfillment dimensions and its influence on customers in e-tailing: a critical review. Asia Pacific Journal of Marketing and Logistic, 29 (2).

Jauhari, M. T., Kusumawati, A., \& Nuralam, I. P. (2019). The Impact of Website Quality on Consumer Satisfaction and Purchase Intention (Study Case of E-Commerce Lazada Indonesia in Malang City). Jurnal Administrasi Bisnis, 67 (1).

Kurniawati, Kusyanti \& Murssityo (2018). Analsis Pengaruh Kualitas Website Terhadap Kepuasan Pelanggan Mister Aladin Dengan Menggunakan Webqual 4.0. Jurnal Pengembangan Tekonologi Informasi Dan IImu Computer, 2 (3). 1151-1160

Lathiras, et al. (2011). Assessing The Impact Of Website Quality On User Satisfaction: A Study Of Webqual And Net Promoter Score In Hotels. $4^{\text {th }}$ Annual EuroMed Conference Of The EuroMed Academy Of Business, pp. 1058-1073

Liu, C., \& Arnett, K. P. (2000). Exploring the factors associated with Web site success in the context of electronic commerce. Information \& management, 38(1), 23-33. 
Jurnal Personalia, Financial, Operasional,

Marketing dau Sistem Informasi

Performance. Volume 28 Nomor 1 Tahun 2021, 82-92

Lovelock, C., \& Wirtz, J. (2011). Perspektif Pemasaran Jasa edisi 7. Jakarta: Erlangga Saputri

Muhsin, A., \& Zuliestiana, D. A., (2017). Analisis Pengaruh Kualitas Website (WebQual) 4.0 Terhadap Kepuasan Pengguna Bukalapak di Kota Bandung. e-Proceeding of Management, 8 (3).

Parasuraman, A., Zeithaml, V.A., \& Malhotra, A. (2005). E-S-QUAL: A Multiple-item Scale for Assessing Electronic Service Quality. Journal of Service Research, 7 (3).

Ranjbarian, Bahram, et al. (2012). An Analysis Of Brand Image, Perceived Quality, Customer Satisfaction and Re-Purchase Intention in Iranian Department Stores. Journal of Business and Management. 7 (6).

Rinaldi, A. \& Santoso, S.B. (2018). Analisis Pengaruh Kualitas Informasi, Kualitas Sistem Dan Kualitas Pelayanan Terhadap Minat Beli Ulang Dengan Kepuasan Pelanggan Sebagai Variabel Intervening (Studi Pada Pelanggan Traveloka di Kota Semarang). Diponegoro Journal of Management, 7 (2)

Rohwiyati \& Praptiestrini (2019). The Effect Of Shopee E-Service Quality And Price Perception On Repurchase Intention: Customer Satisfaction As Mediation Variable. Indonesian Journal of Contemporary Management Research, 1 (1).

Saputri, D.M., \& Astuti, R.T. (2016). Analisis Faktor-Faktor Yang Mempengaruhi Minat Beli Ulang Produk Customcase Handphone dengan Kepuasan Pelanggan Sebagai Variabel Intervening. Diponegoro Journal of Management, 5 (3)

Schiffman, L.G., \& Kanuk, L.L. (2010). Consumer Behaviour (10th ed). New Jersey: Pearson Prentice Hall.

Suliyanto, Novandari, W. (2019). The Influence of Market Orientation on Marketing Performances in Micro Small and Medium-Sized (MSMEs) Coconut Sugar Enterprises: The Role of Innovation. Quality-Access to Success, 20(172).

Supriyantini, Suyadi, I., \& Riyadi. (2014). Pengaruh Efficiency, Fulfillment, System Availability, dan Privacy terhadap satisfaction. Jurnal Administrasi Bisnis (JAB), 5 (2).

Sugiyono. (2017). Metode Penelitian Kuantitatif, Kualitatif, dan R\&D. Bandung: CV. Alfabeta.

Tjiptono, F. (2014). Pemasaran Jasa, Prinsip, Penerapan, dan Penelitian. Yogyakarta: Andi Offset. 